\title{
A White Counselor in a Multicultural World: Understanding the Need for a Spiritual, Multicultural Counseling Course
}

\author{
Kate Walsh Soucheray ${ }^{1(0)}$ \\ ${ }^{1}$ Ed.D., M.A.T., M.A., LMFT, The Institute for Family Health and Well-being, Minnesota, USA
}

\section{Corresponding author: \\ Kate Walsh Soucheray \\ E-mail: \\ katewalshsoucheray@ gmail.com}

eISSN: 2458-9675

Received: 25.11 .2019

Revision: 13.04.2020

Accepted: 22.04.2020

(C) Copyright 2020

by Author(s)

\begin{abstract}
Multicultural counseling must be seen a significant factor in today's multicultural world as therapists provide therapeutic services off ered to clients, especially clients who have immigrated from one country to another within the past 50 years. Multicultural counseling refers to the preparation and practices that help White counselors learn to integrate multicultural and culture-specific awareness, knowledge, and skills into counseling interactions into their practice with multicultural clients. White counselors who work with multicultural clients have the choice to either remain handmaidens of the status quo or transmitters of society's values or become agents of change. Additionally, it has been demonstrated that White counselors who have participated in a multicultural training program have greater therapeutic skill to offer their multicultural clients. Furthermore, when multicultural counseling is incorporated in a spiritually-enriched therapeutic relationship, White counselors are able to relate more effectively with their multicultural clients. A spiritually-enriched therapeutic relationship off ers counselors the opportunity to work with their multicultural clients and incorporate the vital aspect of spirituality, because it is universal to human existence.

Therefore, through the use of spirituality in multicultural counseling, White counselors must have the desire to understand their multicultural clients' worldview, which incorporates the view these clients have of their spirituality. Counselors must understand the importance of developing a curiosity to understand how spirituality influences the lives of their multicultural clients and use this new awareness to help facilitate healing and wholeness for their clients.
\end{abstract}

Keywords: Ethnocentric, Ethnorelative, Multicultural Counseling, Spirituality

Citation: Walsh-Soucheray, K. (2020). A White counselor in a multicultural world: Understanding the need for a spiritual, multicultural counseling course. Spiritual Psychology And Counseling, 5, $203-218$. https://dx.doi.org/10.37898/spc.2020.5.2.86 


\section{Multicultural Counseling}

It is often asked if a therapist of the dominant culture can effectively address the emotional and mental health needs of multicultural clients, which are people from different cultures, spanning national borders, attempting to work cohesively together (Lisak \& Erez, 2015). Even though mental health professionals may have received trainings in multiculturalism and cultural diversity, this does not guarantee they have addressed their biases and prejudice regarding multicultural individuals. In addition to addressing these often-unstated, unacknowledged predispositions toward multicultural clients, White counselors must also become multiculturally aware, responsive, competent, and humble in their work with multicultural clients (Ahmed et al., 2011; Cole et al., 2014; Hays, 2008). The most important concept is multicultural competency (Brach \& Fraser, 2000; Kohn-Wood \& Hooper, 2014), and while it may seem selfevident that multicultural clients are not expecting counselors to be experts in all world cultures, these clients do expect White counselors to be competent, through expressing their willingness to ask questions and learn from their clients (Brach \& Fraser, 2000).

Multicultural clients would prefer to see a counselor or therapist of their own ethnicity (Berger, Zane, \& Hwang, 2014; Hays, 2008), but because there is only a fraction of the needed multicultural counselors to work with multicultural clients, White counselors must gain the competency and understanding to work with clients of many different cultures (Toporek \& Worthington, 2014). The challenge facing White counselors or therapists to gain a strong understanding of therapeutic strategies as they work effectively work with their multicultural clients is attainable. What is required of White counselors as they become multiculturally competent is humility (Hays, 2008; Toporek \& Worthington, 2014), which reveals a counselors' willingness to not have all the answers, but to enter into their client's world and learn from them. Doing so conveys genuine respect and a desire to know more about their client's worldview through asking questions and remaining open and responsive to the world opened up to them. Certainly, counselors are expected to locate the country of origin of their multicultural clients on a world map, understand something of their culture, and develop a curiosity about their way of life in their country of origin before immigrating to a new country. This curiosity and preparation are expected of counselors who work with multicultural clients, as they demonstrate reverence and respect for clients of a culture unfamiliar to them (Hays, 2008; Toporek \& Worthington, 2014).

\section{Responding with Reverence and Respect}

As White counselors respond with reverence and respect to the stories their multicultural clients share, they must tap into the difficult experiences they have had in life, as a way to have empathy for the hardships their clients have faced through immigration, prejudice, and cultural misunderstandings. These difficult experiences 
may include feeling unsure of how to ask certain cultural questions or how to respond appropriately to what may seem a response from a multicultural client that the White counselor does not fully understand (Johnson, 2013). The more effectively a White counselor is able to relate to the stories their clients share, the better able they will be in offering empathically successful, helpful strategies and suggestions to assist them with the issues they face. Vitally important will be the compassion and understanding they convey to their clients, who will be keenly aware of any judgment or discrimination communicated toward them, regarding customs or behaviors that seem unusual to the counselor. If these counselors are able to relate to their clients, person-to-person, they will likely be met with relief, warmth, and openness to the therapeutic ideas they offer (Hays, 2008; Toporek \& Worthington, 2014).

An important factor to help White counselors develop a therapeutic relationship with multicultural clients is the willingness to gain a more comprehensive understanding of their clients' worldview, rather than to making assumptions about the values they hold (Sue \& Sue, 2003). Multicultural clients may now be living in a new country and White counselors may have biases and prejudices, even unacknowledged, and they must be willing to see their multicultural clients as people who are struggling, rather than as people who must fit into a system that is unfamiliar to them (Hays, 2008). White counselors and therapists must become agents of change in our current culture so that they can make a difference in the lives of their multicultural clients (APA, 2002). Counselors and therapists will become agents of change when they willing accept their therapeutic responsibility to understand the cultural differences between themselves and their multicultural clients. This may require counselors and therapists to challenge their own worldview and their own perspective regarding the cultural differences that exist between themselves and their multicultural clients (APA, 2002; Hays, 2008).

To do so most effectively, White counselors must understand their own limitations, which may include prejudices that exist of which they are unaware, as well as biases they may have accepted about multicultural groups, by expressing their willingness to ask questions as they listen and learn from their multicultural clients, entering into difficult dialogues that encourage multicultural clients to tap into their own personal strengths and resources (Hays, 2008; Toporek \& Worthington, 2014).

Sue and Sue (2003) explain:

It is clear that the culturally effective family systems therapist must escape from his or her cultural encapsulation, necessarily understand the sociopolitical forces that affect minority families, become aware of major differences in the value system that he or she possesses when contrasted with racial/cultural family values, and understand structural family relationships that are different from his or her own concepts of family (p. 158). 
To achieve this level of self-awareness, a White counselor must engage in a process of examining their own worldview so that they may more effectively understand the differences that exist between their worldview and the worldview of their multicultural clients. Sue and Sue (2003) provide the Value-Orientation Model to facilitate a better understanding of cultural differences that exist between a White counselor and their multicultural clients. This model requires that a counselor begin with an examination of their temporary focus of human life, or the Time Focus category, which necessitates a response of its meaning from a past, present, and future orientation perspective. Next, the question of the modality of human activity, or the Human Activity category, which again necessitates responding from the perspective of past, present, and future. This is followed by responding to the question of the way human relationships are defined, or Social Relations, from the perspective of past, present, and future. Finally, the relationship of the people to nature, or People/Nature Relationship, is evaluated from a past, present, and future orientation (Kluckholm \& Strodtbeck, 1961, as cited Sue and Sue, 2003).

As their clients navigate the demands of a new country, with a new language, new customs, new educational system, and new ways of dressing and interacting with one another, White counselors and therapists have the opportunity to extend a gracious welcome, as they offer assistance throughout the immigration process. In doing so, White Counselors will gain a more thorough understanding of the cultural differences that exist between themselves and their multicultural clients (Cole et al., 2014; Hays, 1996; Hays, 2008; Hays, 2014; Kohn-Wood \& Hooper, 2014; Sue \& Sue, 2003; Toporek \& Worthington, 2014).

Counselors may wish to engage new learning and training to help themselves more effectively understand newcomers to their country. They may wish to enter into immersion experiences, or field trips, and have first-hand experiences of the various cultures they will encounter in their offices (Cole et al., 2014; Hays, 1996; Hays, 2008; Hays, 2014; Kohn-Wood \& Hooper, 2014). They may wish to eat the foods of these new cultures (Bhahuk \& Brislin, 1992) and enter into difficult dialogues, or discussions with individuals from other cultures that may facilitate discomfort or uneasiness that they would prefer to avoid (Toporek \& Worthington, 2014). Such discussions will more likely occur when counselors engage in experiences that require them to go into neighborhoods which may be unfamiliar them, in order to interact with people of a culture different than their own, which will give them the opportunity to associate with these multicultural individuals in their own environment. Doing so will help these counselors and therapists gain first-hand experiences with individuals of an unfamiliar culture. It will be important to engage in difficult dialogues with other counselors about how they were challenged through the engagement with the culture, as they actively engage the opportunity to discuss these cultural differences and what they have learned (Toporek \& Worthington, 2014). 
In doing so, the counselors will demonstrate their willingness to become agents of change (APA, 2002) rather than handmaidens of the status quo or transmitters of society's values (Sue \& Sue, 2003) and remain unaffected by the cultural differences that would help them become more empathic, responsive counselors (Ahmed et al., 2011; Cole et al., 2014; Hays, 2008). Becoming an agent of change requires a White counselor to gain a thorough understanding of their own worldview so they may more effectively understand the worldview of their multicultural clients. Doing so will help their multicultural clients gain a better understanding of themselves as they engage in a new culture and attempt to adjust to their new life in a new, and often unfamiliar, culture. At the same time, the culture itself must change, and the White counselor could we viewed as the bridge that spans the two (Bean \& Titus, 2009).

\section{The Importance of Multicultural Training for Self-Understanding}

In order to become the bridge that spans the two cultures, White counselors must be willing to challenge the ethnocentric beliefs they hold and enter into an ethnorelative perspective regarding the multicultural clients with whom they work (Barden, Shannonhouse, \& Mobley, 2015). An ethnocentric belief occurs when observations are made from an individual's own point of view (Sue et al., 1992), whereas an ethnorelative belief occurs when an individual observes people and situations from a perspective of openness to new perspectives that may challenge them (Cole et al., 2014; Kluckholm \& Strodtbeck, 1961, as cited in Sue \& Sue, 2003).

This new perspective may be foreign to White counselors, which requires the counselor to enter into difficult dialogues with their multicultural clients, as well as other counselors, as they ask for help to understand the cultural issues more compassionately and empathically (Toporek \& Worthington, 2014). It is in these moments that humility must take precedence over arrogance, as the counselor is humbly encouraged to assume the therapeutic stance of not knowing, so that multicultural clients will openly and confidently share their immigration stories, their first experiences in a new country, as well as incidences of prejudice or injustices they have encountered (Nichols, 2005; Wamser-Naney \& Vandenberg, 2013). These experiences may include traumatic events, which must be processed if the multicultural client is to more fully enter into everyday life experiences (Goodman, Vesely, Letiecq, Cleaveland, 2017). See the diagram below, the Effects of Trauma on Survivors, for a deeper understanding of the types of traumatic experiences multicultural clients share with their counselors. 
Figure 1.

The Effects of Trauma on Survivors.

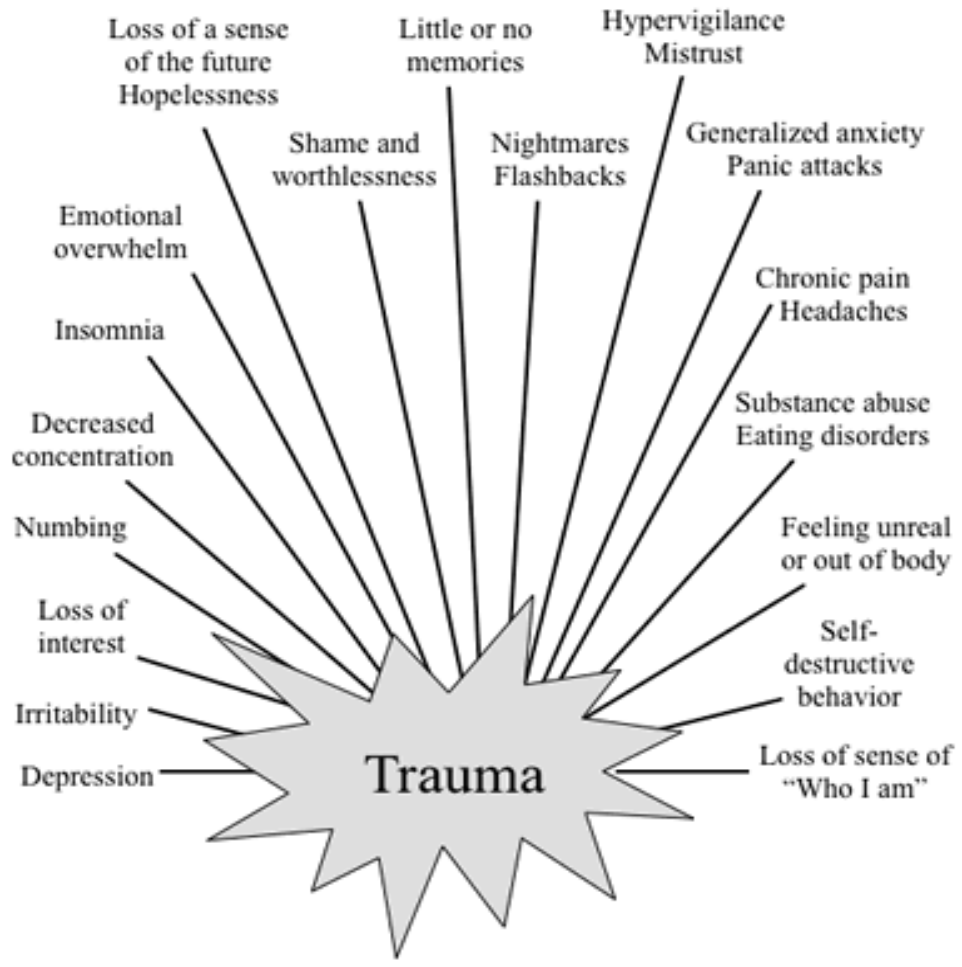

"Trauma survivors have symptoms instead of memories" [Hancy, 1990]

Adapted from Bremner \& Marmer, 1998

Copynight 2007 Janina Fisher, Fh.D.

The Effects of Trauma on Survivors

As White counselors listen to incidences of trauma, second-hand trauma may occur for them as they attend to the highly-charged emotional events their clients share. Second-hand trauma may contribute to the difficulty a White counselor experiences when attempting to understand their multicultural client's worldview. To prevent traumatic responses in their own lives, counselors must be attentive to processing second-hand trauma (Caffrey, 2018). As counselors help their clients process the traumatic events they share, they must remind these clients of their strengths, which occurs as the counselor gains a better understanding of the lives of their clients who have immigrated from their home country to another country of the world. As counselors gather information found on the diagram below, Improving 
Cultural Competence, they will have the opportunity to help their multicultural clients understand their strengths and abilities to overcome difficulties. Through entering into difficult dialogues with other practioners, White counselors have the opportunity to discuss unfamiliar and uncomfortable feelings, thoughts, and reactions to the encounters they have with their multicultural clients with supervisors or other counselors in consultation (Toporek \& Worthington, 2014, Leuwerke, 2005) These uncomfortable feelings, thoughts, and reactions may occur when a White counselor visits a Hispanic, Somalian, or Hmong cultural center and hears immigration stories that explain the difficulties experienced by the individuals who have immigrated from one country to another. Prior to these encounters, a White counselor may have held the misconception that they understood the difficulties, whereas upon hearing firsthand encounters, they realize that they do not. As their cultural competence develops and improves, White counselors will be able to appreciate a more thorough understanding of their clients' lives, struggles, and personal needs. Improving Cultural Competence is a means by which counselors talk about immigration experiences with their multicultural clients, eliciting information in each area presented, in an effort to help identify specific concerns, as well as successes.

Through the use of Kluckholm \& Strodtbeck's Value Orientation Model (as cited in Sue \& Sue, 2003), a White counselors' application of the Improving Cultural Competence Model (Center for Substance Abuse Treatment, 2016) provides the opportunity for counselors to gain a deeper understanding of their own worldview, facilitating greater awareness of their multicultural clients' worldview. As they do so, White counselors may become the bridge between their multicultural clients and the culture to which they are immigrating (Bean \& Titus, 2009).

\section{Improving Cultural Competence}

In order to gain a better understanding of a counselor's own personal perspectives on life and interactions with others, counselors will find it helpful to address aspects of their own Personal Identity Model, through the use of Allport and Odbert's Personal Identity Model (Allport \& Odbert, 1936). Following the examination of their own personal qualities and approaches to life, counselors will ideally gain a deeper understanding of themselves as they examine their own unique characteristics as a human being. Next, they will gain a deeper understanding of their place within the group to which they belong, identifying ethnicity, gender, socioeconomic status, age, marital status, cultural differences, sexual orientation, religious affiliation, disabilities they experience, and where they live geographically. Finally, as they locate their place among other human beings, through the use of the Values Orientation Model (Kluckholm \& Strodtbeck, as cited in Sue \& Sue, 2003) and the use of the Improving Cultural Competence Model (Center for Substance Abuse Treatment, 2016), White 
Figure 2.

Center for Substance Abuse Treatment (2016). Improving Cultural Competence. https://www.ncbi.nlm.nih.gov/ books/NBK248423/

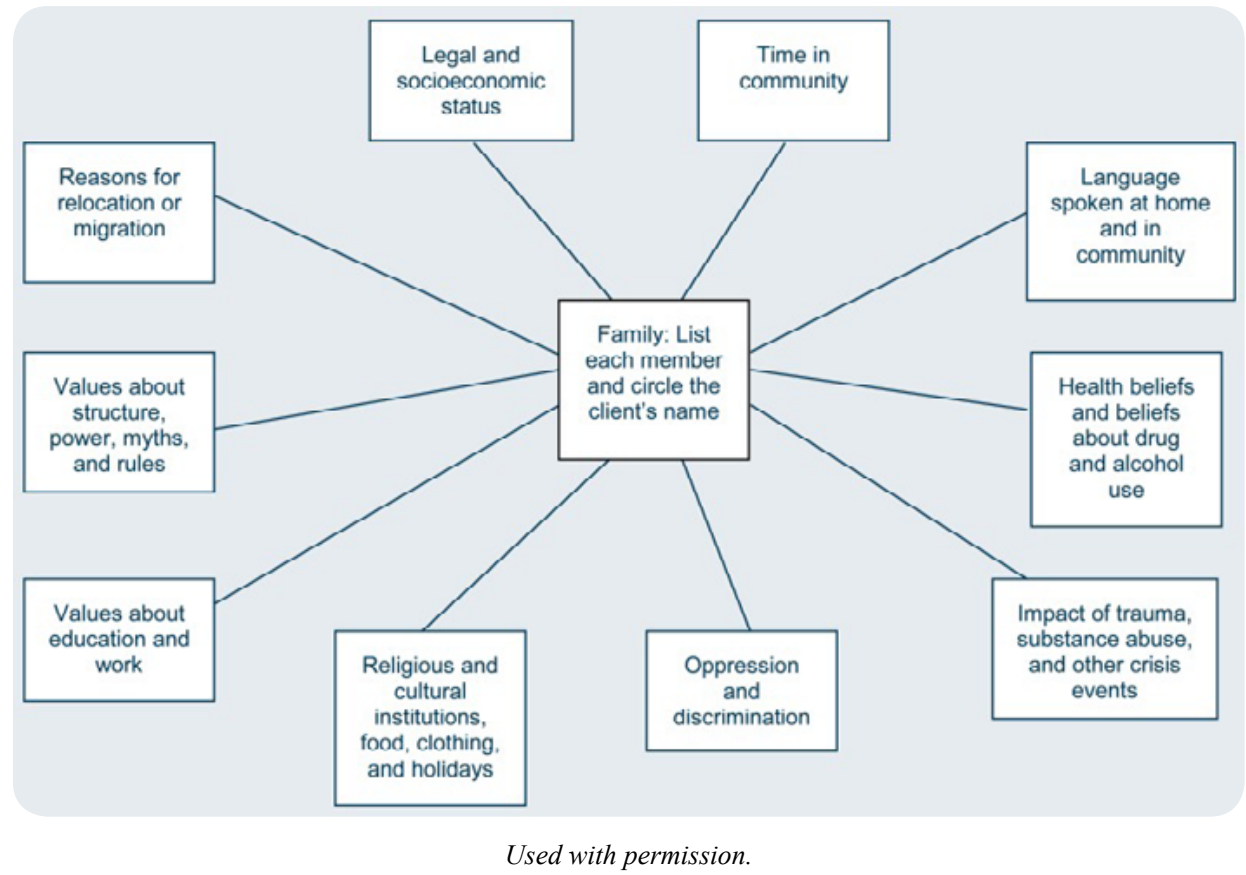

counselors will ideally identify common life experiences between themselves and their multicultural clients, as well as biological and physical similarities, their level of self-awareness, and their ability to use symbols to help them become more aware of their worldview and the worldview of their multicultural clients (Allport \& Odbert, 1936; Bean \& Titus, 2009; Center for Substance Abuse Treatment, 2016; Kluckholm \& Strodtbeck, as cited in Sue \& Sue, 2003).

Following the examination of the aspects of the Personal Identity Model, counselors will ideally have gained a better understanding of themselves, facilitating the development of an effective, respectful Ethical Working Alliance with their multicultural clients, which is a collaborative partnership formed between the counselor and their multicultural client (Dawson, 2017). An Ethical Working Alliance is a relationship founded on complexity and cooperation, especially regarding the respect a White counselor demonstrates toward their multicultural client's worldview and the therapeutic needs they present which the counselor may not fully understand. The complexity introduced to the therapeutic relationship, due to misunderstandings or misconceptions, requires cooperation between the counselor and the client multicultural client to help reduce the impact these misunderstood impressions could potentially create (Dawson, 2017). 
The respect between a White counselor and multicultural clients occurs when the counselor has a thorough understanding of the similarities and differences that exist between themselves and their multicultural clients, which evolves through the empathy and insight that develops through the use of the Personal Identity Model (Allport \& Odbert, 1936; Sue, 2001). This demonstration of respect conveys to the multicultural client the esteem the counselor holds for them, their experiences, their perceptions, and the issues they bring to therapy. Doing so communicates the counselor's willingness to see their multicultural clients as individuals to be cared for, rather than individuals to fear, to hold in contempt, or to fix (Bean \& Titus, 2009; Dawson, 2017; Hays, 2014; Sue, 2001).

Figure 3

An ethical working alliance. Dawson, 2017. Used with permission.

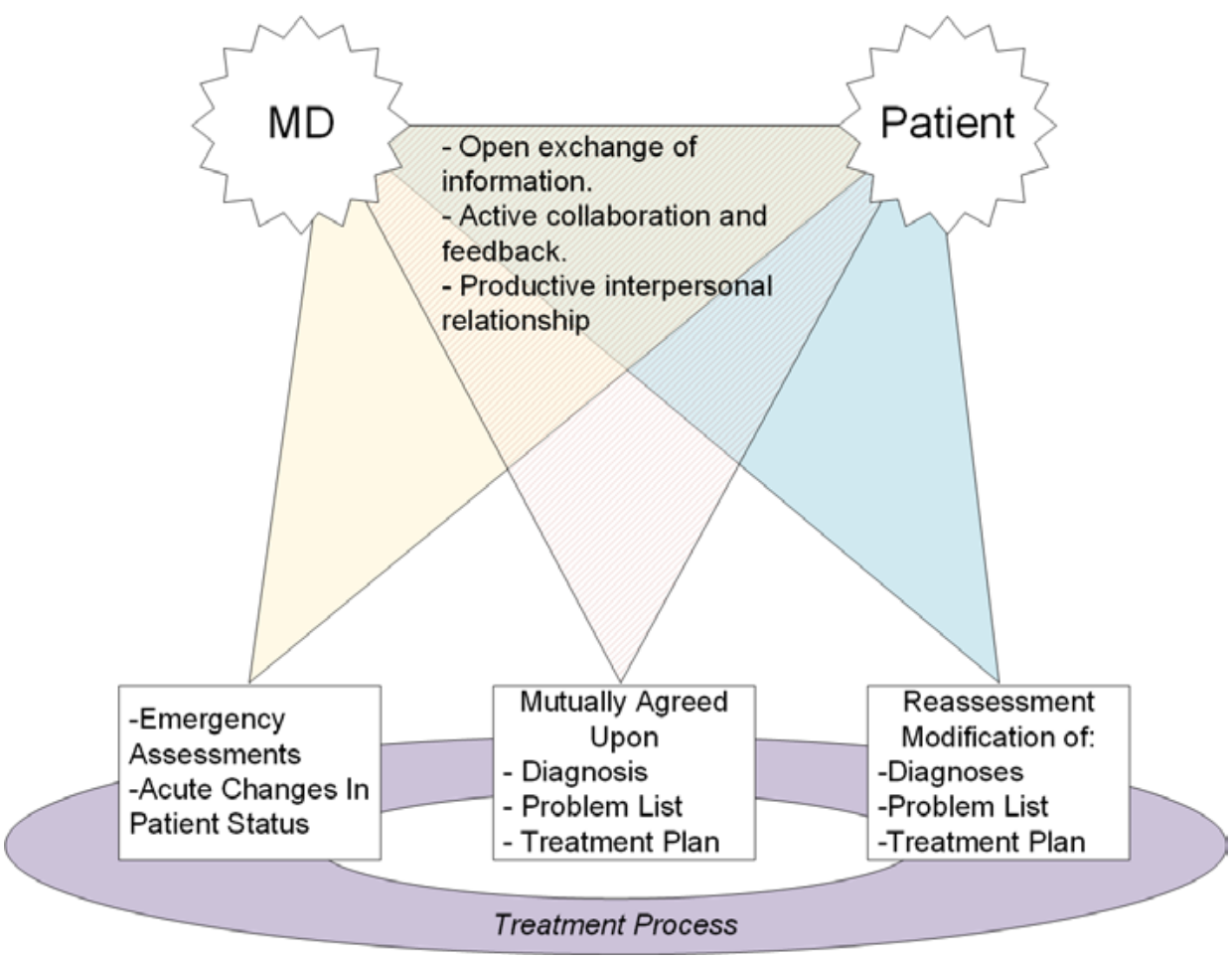

Diagram of an Ethical Working Alliance

As multicultural clients come to this country, they do so with a mixture of excitement, reservation, fear, hope, anticipation, and reluctance, all of which contribute to the way they perceive themselves and others (Ahmed et al., 2011; Berger et al., 2014; Cole et al., 2014; Hays, 2008; Sue et al., 1992). It is for these reasons that multicultural clients often prefer to see a multicultural counselor, which is a counselor of an ethnicity different from the dominant culture. Multicultural clients explain they would prefer to 
see a counselor of an ethnicity different from the dominant culture, even an ethnicity different than their own, because they believe multicultural counselors understand the unique dynamic of being a multicultural person, couple, or family in a culture that is different than their own (Ahmed et al., 2011; Berger et al., 2014; Cole et al., 2014; Hays, 2008). Unfortunately, multicultural counselors are difficult to find and most multicultural clients must choose between seeing a counselor of the dominant culture, whom they often fear will judge them; talking to their family medical doctor, who may not know how to effectively treat mental health issues or do not have adequate time to do so; talking to family members, who may offer some solutions; or suffering in silence (Ahmed et al., 2011; Berger et al., 2014; Cole et al., 2014; Hays, 2008; Sue et al., 1992). When counselors of the dominant culture work to form an Ethical Working Alliance with their multicultural clients, they have the opportunity to develop a greater sense of empathy and compassion for these clients and are better able to offer therapeutic services that are uniquely attuned to their needs (Dawson, 2017).

\section{The Therapeutic Needs of Multicultural Clients and the Use of Spirituality}

In empathically addressing a multicultural clients' therapeutic needs, the use of spirituality may be helpful, because spirituality has often contributed to the foundation of their success throughout the immigration process (Johnson, 2015: Sue \& Sue, 2003). Sue and Sue (2003) argue "counseling and psychotherapy have historically neglected the spiritual dimension of human existence" (p. 198). For many multicultural clients, spirituality is the aspect of life in which "the spirit, mind, and body are all interconnected" (Sue $\&$ Sue, 2003, p. 316). Furthermore, for multicultural clients "spirituality and religious beliefs can be source of inner strength and support" (Sue \& Sue, 2003, p. 433).

Johnson (2013) explains that when a counselor works therapeutically with a multicultural client, they must "conceptualize client worldviews as containing a variety of factors that combine to create a lens through which they define and experience themselves in the world" (p. 8). Additionally, Johnson contends that "both clients and therapists bring their cultural lens to the therapy room" (p. 8) and that counselors must follow three general steps when working with multicultural clients: they must know themselves culturally, they must be open to understanding their clients cultural background, and they must be open to the interface where the perspectives two meet (Johnson, 2013).

Johnson (2013) argues spirituality is understood as a fundamental aspect of a person's cultural composition, however, "some therapists do not have a clear idea of their [own] spiritual and religious beliefs" (p. 9). He contends that most therapists have a clear idea of their racial biases and perspectives regarding sexual orientation, however, "spiritual and religious issues seem to be another story" (p. 9). Yet, even 
though clients may not request that spiritual practices to be incorporated into their therapeutic plan, Johnson explains "clients seem to benefit from treatment that incorporates their spiritual and religious framework" (Johnson, 2013, p. 10).

The omission of the use of a spiritual or religious perspective in therapeutic practices was created through three prevalent perspectives: Freud, Scientific Rationalism, and Value-Free Therapy (Johnson, 2013). Johnson explains that Freudian Therapy discouraged therapist self-disclosure, because he believed it could interfere with the dynamics of the change process and was "often seen as gratifying the therapist's needs at the expense of the therapeutic process" (p. 11).

Scientific Rationalism proposed that science would "eventually find the answers to all of life's mysteries, thereby rendering religion as archaic and unnecessary" ( $p$. 13). Finally, Value-Free Therapy comes from the humanist therapeutic perspective and proposes that, unless therapists are value-free, they may impose their belief systems on clients and therefore "attempts to integrate religion or spirituality into the therapy process is viewed with skepticism" (Johnson, 2013, p. 14).

When White counselors integrate spirituality into the therapeutic relationship with their multicultural clients, it often provides a significant means of therapeutic connection between the counselor and client because it allows the counselor to express their sense of not-knowing and a perspective of working collaboratively to find solutions to the issues their clients face (Johnson, 2013; Nichols, 2005; Wheatley, 2005). According to Wheatley (2005), when counselors integrate spirituality into their therapeutic work with multicultural clients, they are thinking systemically and tapping into the oneness of which every spiritual tradition speaks.

It is the oneness and the spiritual integration that is shared between the counselor and client that helps facilitate healing (Wheatley, 2005). Sue and Sue (2003) concur as they establish the importance of spirituality for immigrants, due to its healing qualities, which exist outside of what can be intellectually known. To be an effective multicultural counselor, White counselors would benefit from understanding the mystical and mysterious aspect of spirituality for many of their multicultural clients and integrate it into their work (Sue \& Sue, 2003).

Sue and Sue (2003) explain that Western counselors have often ignored the allimportant aspect of emotional healing through the integration of spirituality in the therapeutic relationship with their multicultural clients, whereas non-Western cultures "often rely on the spiritual plane of existence in seeking a cure" (Sue \& Sue, 2003, p. 189). Furthermore, through the use of spirituality, harmony and balance are often achieved, as opposed to the Western concepts of separation, isolation, and individualism, which are so often favored in these cultures as indications of success 
(Sue \& Sue, 2003). Wheatley (2005) agrees, contending that "nothing in the universe exists as an isolated or independent entity" (p. 219), rather, "everything takes form from relationships" (p. 219). Wheatley continues "in the web of life, nothing living lives alone" (p. 219).

\section{Multicultural Counseling and Becoming an Agent of Change}

Sandage, Wibberley, and Worthington(1995)contend the fourth force of the counseling practice is multiculturalism, and from a Christian perspective, multiculturally-aware, sensitive, responsive, competent, humble counselors must ask themselves "What do I have to offer?" (p. 30) as they encourage and strengthen a sense of community and belonging for their multicultural clients. The authors state that most world cultures stress interdependence and collectivism, and when a dominant-culture counselor works therapeutically with multicultural clients, they must help these clients "overcome a sense of fragmented isolation by helping them orient their individual stories into a larger, cosmic story" (p. 32). When related to the concept of story, counselors have the opportunity to tap into "the vital strength of the Christian community [through the] telling and retelling of stories that make heroes out of the 'ordinary' people who rely on an extraordinary God" (Sandage et al., 1995, p. 32).

Understanding the difference in perspectives between White counselors and their multicultural clients, Bean and Titus (2009) argue "the overwhelming need for information and guidance in working with ethnically diverse clients is, for the most part, accompanied by an undersupply of clear culturally relevant treatment recommendations" (p. 40). To meet this underserved need, the authors encourage practioners and researchers to address the cultural and clinical relevancy of "the client's ethnic culture and the culture of the presenting problem" (Bean \& Titus, 2009, p. 40). Therefore, when a White counselor enters the world of their multicultural client to learn about their worldview and phenomenological view of life, they are working empathically to understand what it is like to be in their world, helping the client begin their healing work (Gladding, 2004). Rogers believes that when a client receives unconditional positive regard from a counselor, through empathic listening, the client is able to develop congruency, which is "the condition of being transparent in the therapeutic relationship by giving up roles and facades" (Rogers, 1980, as cited in Gladding, 2004, p. 201).

In order to facilitate transparency in the therapeutic relationship, the counselor must be willing to forego what they think they understand of their multicultural client's world and enter into the world their client shares, humbly asking questions and learning from them in order to help them. They must be willing to become ethnorelative and learn about the experiences their multicultural clients share, rather than imposing an ethnocentric perspective on them and the concerns they bring to therapy, which would 
be considered unethical therapeutic practice because it could be perceived as coercive and intimidating (Cole et al., 2014; Gladding, Remley, \& Huber, 2001).

It is for this reason that a White counselor would likely benefit from training that helps them understand and address their biases regarding multicultural clients (Arredondo \& Arciniega, 2001; Fairburn \& Cooper, as cited in Kohrt, Jordans, Rai, Shresha, Luitel, Ramaiya, Singla, \& Patel, 2015). This would ideally help them address unacknowledged biases, because bringing bias to the therapeutic relationship is unethical, and therefore should be avoided (Gladding et al., 2001). However, through taking time and expending energy to humbly learn about the cultures and customs of their multicultural clients, White counselors enter into a collaborative counseling posture of not-knowing with their multicultural clients, providing the basis for an openness to learn about the culture represented by their multicultural client (Hays, 2008; Nichols, 2005). It is vitally important that White counselors who work with multicultural clients understand their own limitations and shortcomings, with regard to their understanding of their client's worldview, and humbly undergo an active training process (Arredondo \& Arciniega, 2001; Fairburn \& Cooper, as cited in Kohrt et al., 2015), so they may become agents of change in our world today (APA, 2002).

\section{Results}

White counselors must understand that their most therapeutically-helpful work with multicultural clients will require them to understand the cultural and spiritual complexities that exist between them and their multicultural clients. This will often require White counselors to participate in a training program to help them "integrate multicultural and culture-specific awareness, knowledge, and skills into counseling interactions" (Arredondo et al., 1996, para. 3) with their multicultural clients. Additionally, through the use of a spiritually-enriched therapeutic relationship, White counselors will have the opportunity to understand the vital aspect of spirituality in the counseling relationship with multicultural clients, because spirituality is "universal to human existence" (Faiver, Ingersoll, O'Brien, and McNally, 2001, as cited in Johnson, 2013, p. 28). For many multicultural clients, spirituality is an essential aspect of their life experiences, whereas for White counselors, many are uncertain of the importance of spirituality in their lives (Johnson, 2013). Through gaining an understanding of a multicultural client's worldview, which includes their spirituality, White counselors can help facilitate healing and wholeness for their multicultural clients (Johnson, 2013). 


\section{References}

Ahmed, S., Wilson, K.B., Henriksen, R.C., \& Jones, J.W., (2011). What does it mean to be a culturally competent counselor? Journal of Social Action in Counseling and Psychology, 3(1), 17-28. Retrieved from https://eds-b-ebscohost-com.xxproxy.smumn.edu/eds/detail/ detail?vid=1\&sid=a93252c3-7a14-4fbf-9657-e72ea2d25bf7\%40sessionmgr120\&bdata=JnNpd GU9ZWRzLWxpdmU\%3d\#AN=77572699\&db=aph

American Psychological Association (APA). (2010). Publication manual of the American Psychological Association (6 $6^{\text {th }}$ ed.). Washington, D.C.: American Psychological Association.

Allport, G.W. \& Odbert, H.S. (1936). Trait names: A psycholexical study. Psychological Monographs, 47, 211.

Arredondo, P., Toporek, M. S., Brown, S., Jones, J., Locke, D. C., Sanchez, J., \& Stadler, H. (1996). Operationalization of the multicultural counseling competencies. Journal of Multicultural Counseling and Development, 24(1). Retrieved from https://eds-b-ebscohost-com.xxproxy. smumn.edu/eds/detail/detail?vid=1\&sid=a838283f-7177-4d13-ab0b-2fd682657cf7\%40pdc-vsessmgr05\&bdata=JnNpdGU9ZWRzLWxpdmU\%3d\#AN=RN021540924\&db=edsbl

Arredondo, P. \& Arciniega, G.M. (2001). Strategies and techniques for counselor training based on the multicultural counseling competencies. Journal of Multicultural Counseling and Development, 29(4). 263-273. Retrieved from https://onlinelibrary.wiley.com/doi/ abs/10.1002/j.2161-1912.2001.tb00469.x. doi:10.1002/j.2161-1912.2001.tb00469.x.

Barden, S.M., Shannonhouse, L., \& Mobley, K. (2015). International cultural immersion: Assessing the influence of a group intervention on intercultural sensitivity for counselor trainees. The Journal for Specialists in Group Work, 40(1), 117-141. Retrieved from https://eds-b-ebscohostcom.xxproxy.smumn.edu/eds/pdfviewer/pdfviewer?vid=8\&sid=a93252c3-7a14-4fbf-9657e72ea2d25bf7\%40sessionmgr120. doi:10.1080/01933922.2014.992505

Bean, R.A. \& Titus, G. (2009). Cultural intersection of Asian Indian ethnicity and presenting problem: Adapting multicultural competence for clinical accessibility. Journal of Multicultural Counseling and Development, 37(1). Retrieved from https://eds-b-ebscohost-com.xxproxy.smumn.edu/eds/ pdfviewer/pdfviewer?vid=5\&sid=c4fcfcec-2f85-4cb5-8593-fe3e4b7f098d\%40sessionmgr 103

Berger, L.K., Zane, N., \& Hwang, W. (2014). Therapist ethnicity and treatment orientation differences in multicultural counseling competencies. Asian American Journal of Psychology, 5(1), 53-65. Retrieved from https://eds-b-ebscohost-com.xxproxy.smumn.edu/eds/pdfviewer/ pdfviewer?vid=11\&sid=a93252c3-7a14-4fbf-9657-e72ea2d25bf7\%40sessionmgr 120 .

Bhawuk, D. P., \& Brislin, R. (1992). The measurement of intercultural sensitivity using the concepts of individualism and collectivism. International Journal of Intercultural Relations, 16(4), 413436. Retrieved from https://www.sciencedirect.com/science/article/abs/pii/014717679290031O http://dx.doi.org/10.1016/0147-1767(92)90031-O

Brach, C. \& Fraser, I. (2000). Can cultural competencies reduce racial and ethnic health disparities? A review and conceptual model. Medical Care Research and Review, 67(1), 181-217. Retrieved from https:/www.ncbi.nlm.nih.gov/pmc/articles/PMC5091811/. doi: $10.1177 / 1077558700057001 \mathrm{~S} 09$

Caffrey, C. (2018). Vicarious traumatization (VT). Salem Press Encyclopedia of Health.

Retrieved from https://eds-a-ebscohost-com.xxproxy.smumn.edu/eds/detail/detail?

Vid=1\&sid=bd59064b-5158-4439-a189-4ec9f127ebf8\%40sdc-v-sessmgr03\&bdata=

JnNpdGU9ZWRzLWxpdmU\%3d\#AN=100259369\&db=ers 
Center for Substance Abuse Treatment (2016). Improving Cultural Competence. SAMHSA.

Retrieved from https://www.ncbi.nlm.nih.gov/books/NBK248428/

Cole, E.M., Piercy, F., Wolfe, E.W., \& West, J.M. (2014). Development of the multicultural therapy competency inventory-client version. Contemporary Family Therapy, 36(4), 462473. Retrieved from https://eds-b-ebscohost-com.xxproxy.smumn.edu/eds/pdfviewer/ pdfviewer?vid=23\&sid=a93252c3-7a14-4fbf-9657-e72ea2d25bf7\%40sessionmgr 120 . doi:10.1007/s10591-014-9320-8

Dawson, G. (2017). Therapeutic alliance: A better diagram. Real Psychiatry. Retrieved from https://www.google.com/search?q=diagram + of + an + ethical+working+alliance $\&$ tbm $=$ isch\&source=iu\&ictx=1\&fir=IW3ew6s_1_vCaM\%253A\%252CrKJxYL20ClBrJM\%252C_\&us$\mathrm{g}=\mathrm{AI} 4$ _kQ1613dQTmTyCLkL1wSAzn5cXOvEQ\&sa=X\&ved=2ahUKEwiZ2OPxreHfAhVK74MKHYhLCoUQ9QEwA3oECAAQCg\#imgrc=IW3ew6s_1_vCaM:

Gladding, S.T. (2004). Counseling: A comprehensive profession ( $5^{\text {th }}$ ed.). Upper Saddle River, NJ: Pearson.

Gladding, S.T., Remley, T.P., \& Huber, C.H. (2001). Ethical, legal, and professional issues in the practice of marriage and family therapy ( $3^{\text {rd }}$ ed.). Upper Saddle River, NJ: Merrill Prentice Hall.

Goodman, R.D.; Vesely, C.K.; Letiecq, B.; \& Cleaveland, C.L. (2017). Trauma and resilience among refugee and undocumented immigrant women. Journal of Counseling \& Development, 95(3), 309-321. Retrieved from https://eds-b-ebscohost-com.xxproxy.smumn.edu/eds/detail/ detail?vid=1\&sid=eeeeb7b1-c8d4-4cab-a016-6c8009af9b84\%40sessionmgr101\&bdata=JnNpd GU9ZWRzLWxpdmU\%3d\#AN=123715847\&db=tfh. doi: 10.1002/jcad.12145

Hays, P.A. (2008). Addressing cultural complexities in practice: Assessment, diagnosis, and therapy $\left(2^{\text {nd }}\right.$ ed.). Washington, D.C.: American Psychological Association.

Hays, P.A. (2014). An intercultural perspective on the adaptation of CBT across cultures. Australian Psychologist, 49(1), 17-18. Retrieved from http://onlinelibrary.wiley.com/doi/10.1111/ap.12027/ full. doi:10.111/ap.12027

Johnson, R (2013). Spirituality in Counseling and Psychotherapy: An Integrative Approach that Empowers Clients. Hoboken, NJ: John Wiley \& Sons.

Kohn-Wood, L.P. \& Hooper, L.M. (2014). Cultural competency, culturally tailored care, and the primary care setting: Possible solutions to reduce racial/ethnic disparities in mental health care. Journal of Mental Health Counseling, 36(2), 173-188. Retrieved from https://www. researchgate.net/publication/266558774_Cultural_Competency_Culturally_Tailored_Care_ and_the_Primary_Care_Setting_Possible_Solutions_to_Reduce_RacialEthnic_Disparities_in_ Mental_Health_Care. doi:10.17744/mehc.36.2.d73h217181tg6uv3.

Kohrt, B.A., Jordans, M.J.D., Rai, S., Shresha, P., Luitel, N.P., Ramaiya, M.K., Singla, D.R., \& Patel, V., (2015). Therapist competence in global mental health: Development of the Enhancing assessment of therapeutic factors. Behavior Research and Therapy, 69(11), 11-21. Retrieved from https://www-sciencedirect-com.xxproxy.smumn.edu/science/article/pii/S0005796715000480. doi: 10.1016/j.brat.2015.03.009.

Leuwerke, W. (2005). Fostering the development of multicultural counseling competencies: Training, growth, and development for White counselors. Guidance \& Counseling, 21(1), Retrieved from https://eds-b-ebscohost-com.xxproxy.smumn.edu/eds/detail/detail?vid=3\&sid=52214e 1 b0176-4f2b-87d4-ecf345044f4e\%40pdc-v-sessmgr03\&bdata=JnNpdGU9ZWRzLWxpdmU\%3d $\# \mathrm{AN}=21036572 \& \mathrm{db}=\mathrm{keh}$ 
Lisak, A., \& Erez, M. (2015). Leadership emergence in multicultural teams: The power of global characteristics. Journal of World Business, 50(1), 3-14. Retrieved from https://www. researchgate.net/publication/260109971_Leadership_emergence_in_multicultural_teams_The power_of_global_characteristics?enrichId=rgreq-fc393bf4ef61f2c7e9de9d49af234710-XXX \&enrichSource $=$ Y292ZXJQYWd1OzI2MDEwOTk3MTtBUzo2NTc5MjM4NTY0MTY3Nj1A MTUzMzg3MjY3OTY5MA\%3D\%3D\&el=1_x_3\&_esc=publicationCoverPdf. doi:10.1016/j. jwb.2014.01.002

Nichols, M.P. (2005). The essentials of family therapy ( $2^{\text {nd }}$ ed.). Boston, MA: Pearson.

Sandage, S.J., Wibberley, K.H., \& Worthington, E.L. (1995). Christian counselors' resources for multicultural understanding and counseling. Journal of Psychology and Theology, 23(1), 30-36. Retrieved from https://psycnet.apa.org/record/1995-41472-001

Sue, D. (2001). Personal identity model. Retrieved from https://www.researchgate.net/ publication/240280354_Multicultural_Facets_of_Cultural_Competence/figures?lo=1

Sue, D.W. \& Sue, D. (2003). Counseling the culturally diverse: Theory and practice ( $4^{\text {th }}$ ed.). New York, NY: John Wiley \& Sons, Inc.

Sue, D.W., Arredondo, P., \& McDavis, R.J. (1992). Multicultural counseling competencies and standards: A call to the profession. Journal of Counseling and Development, 70(4), 477-486. Retrieved from https://s3.amazonaws.com/academia.edu.documents/42023810/ Multicultural_Counseling_Competencies_an20160203-20453-vgynih.pdf?AWSAcces sKeyId=AKIAIWOWYYGZ2Y53UL3 A \&Expires $=1513173095 \&$ Signature $=5 \mathrm{kDwDb}$ SWofnd6uSQw01 IgAKfNBY\%3D\&response-content-disposition=inline \%3B\%20filename\%3DMulticultural_Counseling_Competencies_an.pdf; doi:10.1002/j.1556-6676.1992. tb01642.x. doi:10.1002/j.2161-1912.1992.tb00563.x.

Toporek, R.L. \& Worthington, R.L. (2014). Integrating service learning and difficult dialogues pedagogy to advance social justice training. The Counseling Psychologist, 42(7), 919-945. Retrieved from https://eds-b-ebscohost-com.xxproxy.smumn.edu/eds/detail/detail?vid=67\&sid=a 93252c3-7a14-4fbf-9657-e72ea2d25bf7\%40sessionmgr120\&bdata=JnNpdGU9ZWRzLWxpd$\mathrm{mU} \% 3 \mathrm{~d} \# \mathrm{AN}=\mathrm{RN} 360431196 \& \mathrm{db}=$ edsbl. doi:10.1177/0011000014545090

Wamser-Nanny, R. \& Vandenberg, V.R. (2013). Empirical support for the definition of a complex trauma event in children and adolescents Journal of Traumatic Stress 26(6), 671-678. Retrieved from https://complextrauma.org/wp-content/uploads/2019/01/Complex-Trauma-6.pdf. doi: $10.1002 /$ jts. 21857

Wheatley, M. J. (2005). Finding our way: Leadership for an uncertain time. San Francisco, CA: Berrett-Koehler Publishers. 